\title{
Solar Photoelectro-Fenton Degradation of Acid Orange 7 Azo Dye in a Solar Flow Plant: Optimization by Response Surface Methodology
}

\author{
Enric Brillas $^{1} \cdot$ Sergi Garcia-Segura ${ }^{1}$
}

Received: 2 May 2016 /Revised: 17 May 2016 / Accepted: 18 May 2016/Published online: 7 June 2016

(C) Springer Science+Business Media Singapore 2016

\begin{abstract}
The experimental variables to optimize the solar photoelectro-Fenton (SPEF) degradation of $10 \mathrm{~L}$ of Acid Orange 7 (AO7) azo dye in $0.05 \mathrm{M} \mathrm{Na}_{2} \mathrm{SO}_{4}$ of $\mathrm{pH} 3.0$ have been determined from a central composite rotatable design and response surface methodology. Trials were performed with a solar flow plant with a Pt/air-diffusion reactor generating $\mathrm{H}_{2} \mathrm{O}_{2}$ and a solar compound parabolic collector photoreactor under an UV irradiation intensity of about $31 \mathrm{~W} \mathrm{~m}^{-2}$. Optimum variables of $4.0 \mathrm{~A}, 0.75 \mathrm{mM} \mathrm{Fe}^{2+}$, and $150 \mathrm{mg} \mathrm{L}^{-1}$ total organic carbon (TOC) of the azo dye were found for $90 \%$ color and $70 \%$ TOC removals. Under optimized conditions, total decolorization was achieved in 300 min, but AO7 decay obeyed a pseudo-first-order kinetics to disappear in $80 \mathrm{~min}$, pointing to the generation of recalcitrant colored aromatic products. After $360 \mathrm{~min}$ of electrolysis, TOC was reduced by $96 \%$, with $64 \%$ mineralization current efficiency and $133 \mathrm{kWh} \mathrm{kg}^{-1}$ TOC energy consumption. The final solution contained carboxylic acids like tartronic, oxalic, oxamic, and in larger proportion, formic. An almost total mineralization was achieved by SPEF due to the persistence of $\mathrm{Fe}(\mathrm{III})$-formate complexes to be photolyzed by sunlight. The initial $\mathrm{N}$ of the azo dye was mainly released as $\mathrm{NH}_{4}^{+}$.
\end{abstract}

Keywords Acid Orange 7 - Central composite rotatable design $\cdot$ Response surface methodology $\cdot$ Solar photoelectro-Fenton $\cdot$ Oxidation products

Sergi Garcia-Segura

sergigarcia@ub.edu

1 Laboratori d'Electroquímica dels Materials i del Medi Ambient, Departament de Química Física, Facultat de Química, Universitat de Barcelona, Martí i Franquès 1-11, 08028 Barcelona, Spain

\section{Introduction}

A large variety of azo dyes, which represent nearly $70 \%$ of the world's dye production, are widely used as coloring materials in textile and food industries [1-5]. These compounds contain a chromophore group composed of one or more azo $(-\mathrm{N}=\mathrm{N}-)$ groups, usually conjugated with benzene and/or naphthalene systems. As a result of the dyeing process, the textile industries release large volumes of wastewaters with high contents of dyestuffs (usually $100-250 \mathrm{mg} \mathrm{L}^{-1}$ ) that are discharged into natural waters. The entrance of these pollutants into water bodies causes serious environmental risks [6], not only by the visible coloration of waters producing esthetic problems and hindering light penetration but also by health hazards on living beings due to their toxicity, mutagenicity, and carcinogenicity $[5,7,8]$. Azo dyes are very persistent upon natural oxidation and reduction conditions, light exposure, and biodegradation and are hardly removed by physicochemical and biological methods used in sewage treatment plants $[9,10]$. Powerful oxidation methods are necessary to be applied to the remediation of waters contaminated with azo dyes to impede their dangerous impact in the aquatic environment.

Many authors have reported the effective treatment of aqueous solutions of azo dyes by advanced oxidation processes (AOPs) $[1,5,10-13]$. The common feature of AOPs is the in situ generation of reactive oxygen species (ROS), preeminently the hydroxyl radical $\left({ }^{\circ} \mathrm{OH}\right)$ with so high standard reduction potential $\left(E^{\circ}=2.8 \mathrm{~V} / \mathrm{SHE}\right)$ that can oxidize most biorefractory organics up to their mineralization to $\mathrm{CO}_{2}$, inorganic ions, and water. An electrochemical AOP (EAOP) based on Fenton's reaction chemistry like electro-Fenton (EF) has recently received great attention for treating waters contaminated with azo dyes $[3,5,12-16]$. EF consists in the continuous cathodic generation of $\mathrm{H}_{2} \mathrm{O}_{2}$ via $\mathrm{O}_{2}$ reduction (1) upon injection of this pure gas or air into the treated solution or 
directly at a carbonaceous cathode. Small amounts of $\mathrm{Fe}^{2+}$ are added to the medium to react with $\mathrm{H}_{2} \mathrm{O}_{2}$ generating $\mathrm{Fe}^{3+}$ and 'OH in the bulk from Fenton's reaction (2), with optimum $\mathrm{pH}$ about 3 . This reaction is catalytic since it can be propagated from $\mathrm{Fe}^{2+}$ regeneration by cathodic $\mathrm{Fe}^{3+}$ reduction $[5,15]$. A main drawback of $\mathrm{EF}$ is the production of final carboxylic acids that are hardly oxidized by ${ }^{\circ} \mathrm{OH}$. This can be overcome by the photoelectro-Fenton (PEF) process, in which the solution is illuminated with UVA light $\left(\lambda_{\max }=360 \mathrm{~nm}\right)$ upgrading the degradation of organics by (i) a greater $\mathrm{Fe}^{2+}$ regeneration with ${ }^{\circ} \mathrm{OH}$ production from photolytic reaction (3) of photoactive hydroxy-Fe(III) complexes at $\mathrm{pH} 3$ and (ii) the photolysis of $\mathrm{Fe}(\mathrm{III})$ complexes with intermediates like $\mathrm{Fe}(\mathrm{III})$-carboxylate species from reaction (4) [3, 5, 17-21].

$$
\begin{aligned}
& \mathrm{O}_{2(\mathrm{~g})}+2 \mathrm{H}^{+}+2 \mathrm{e}^{-} \rightarrow \mathrm{H}_{2} \mathrm{O}_{2} \\
& \mathrm{Fe}^{2+}+\mathrm{H}_{2} \mathrm{O}_{2}+\mathrm{H}^{+} \rightarrow \mathrm{Fe}^{3+}+{ }^{\circ} \mathrm{OH}+\mathrm{H}_{2} \mathrm{O} \\
& \mathrm{Fe}(\mathrm{OH})^{2+}+h v \rightarrow \mathrm{Fe}^{2+}+{ }^{\circ} \mathrm{OH} \\
& \mathrm{Fe}(\mathrm{OOCR})^{2+}+h v \rightarrow \mathrm{Fe}^{2+}+\mathrm{CO}_{2}+\mathrm{R}
\end{aligned}
$$

The oxidation ability of EF and PEF can be improved using an undivided cell with a high $\mathrm{O}_{2}$-overpotential anode like boron-doped diamond (BDD). This electrode possesses much greater oxidation power than common $\mathrm{Pt}$ and $\mathrm{PbO}_{2}$ anodes [22-25] since it produces higher quantities of physisorbed hydroxyl radicals $\mathrm{M}\left({ }^{\circ} \mathrm{OH}\right)$ from water discharge at the anode M by reaction (5) [22], with ability to slowly oxidize the final $\mathrm{Fe}(\mathrm{III})$-carboxylate complexes.

$\mathrm{M}\left(\mathrm{H}_{2} \mathrm{O}\right) \rightarrow \mathrm{M}\left({ }^{\circ} \mathrm{OH}\right)+\mathrm{H}^{+}+\mathrm{e}^{-}$

In our laboratory, we are developing the solar PEF (SPEF) process that utilizes the free and renewable sunlight as energy source, becoming much more inexpensive than PEF with artificial UVA lamps [3, 26-33] and being more useful for possible application to the industrial level. The best performance of SPEF is feasible because it provides photons in the UV range of $300-400 \mathrm{~nm}$ and in the visible ranges of 400-650 and 400-450 nm, which can also be absorbed for reactions (3) and (4), respectively [34]. Moreover, the action of sunlight in SPEF is so potent that aromatics degradation is quite similar using a Pt or a BDD anode, with the former one being preferable by its lower price and smaller potential difference achieved by the cell yielding less energy consumption [29].

Although several azo dyes have been treated by SPEF [3, 28, 31-33], no studies about the optimization of the experimental variables applied to this process have been previously reported. To explore this possibility, we have studied the SPEF degradation of a monoazo dye such as Acid Orange 7 (AO7), also called Orange II (see its chemical structure and characteristics in Table 1), by checking its optimization from a central composite rotatable design (CCRD) coupled to response surface methodology (RSM) $[27,30,35,36]$. AO7 is widely used for dyeing natural fibers like cotton, silk and wool, silk and cotton, and synthetic fibers like acrylics and polyesters. It has been typically employed as model pollutant to investigate the decolorization and mineralization of azo dyes by different chemical, photochemical, and photocatalytic AOPs [37-41] and EAOPs like EF and PEF [16, 33, 42-48].

This paper presents the results obtained for the optimization of the SPEF degradation of aqueous solutions of $\mathrm{AO} 7$ at pH 3.0 by CCRD and RSM. Experiments were carried out with a 10-L solar flow plant containing an electrochemical cell with a Pt anode and a carbon-polytetrafluoroethylene (PTFE) air-diffusion cathode (Pt/air-diffusion cell) coupled to a photoreactor with solar compound parabolic collectors (CPCs). The decolorization, the kinetic decay and the mineralization of the azo dye, and the evolution of generated shortlinear carboxylic acids and released inorganic ions for the optimized EAOP were determined to clarify the degradation process.

\section{Experimental}

\section{Chemicals}

Commercial pure Acid Orange 7 was supplied by Acros Organics and utilized without further purification. Reagent grade short-linear aliphatic carboxylic acids were purchased from Panreac and Avocado. Solutions were prepared with deionized water by adding $\mathrm{Na}_{2} \mathrm{SO}_{4}$ as supporting electrolyte and $\mathrm{FeSO}_{4} \cdot 7 \mathrm{H}_{2} \mathrm{O}$ as catalyst, both supplied by Fluka. The solution $\mathrm{pH}$ was adjusted to 3.0 with analytical grade $\mathrm{H}_{2} \mathrm{SO}_{4}$ from Merck. Other chemicals were of either high-performance liquid chromatography (HPLC) or analytical grade from Avocado, Fluka, Merck, and Sigma-Aldrich.

\section{Instruments and Analytical Procedures}

The solution $\mathrm{pH}$ was measured on a Crison GLP $22 \mathrm{pH}-$ meter. At regular times, samples of $5 \mathrm{~mL}$ were withdrawn from the treated solutions, neutralized to $\mathrm{pH} 7-8$ for quenching degradation, and filtered with Whatman $0.45 \mu \mathrm{m}$ PTFE filters to be analyzed.

The decolorization of $\mathrm{AO} 7$ solutions was monitored from their absorbance $(A)$ decay at the maximum wavelength of $484 \mathrm{~nm}$ in the visible region (see Table 1), determined on a Shimadzu 1800 UV-vis spectrophotometer thermostated at $35{ }^{\circ} \mathrm{C}$. The decolorization efficiency or percentage of color removal for each sample was calculated from Eq. (6) [5]:

$\%$ Color removal $=\frac{A_{0}-A_{t}}{A_{0}} \times 100$ 


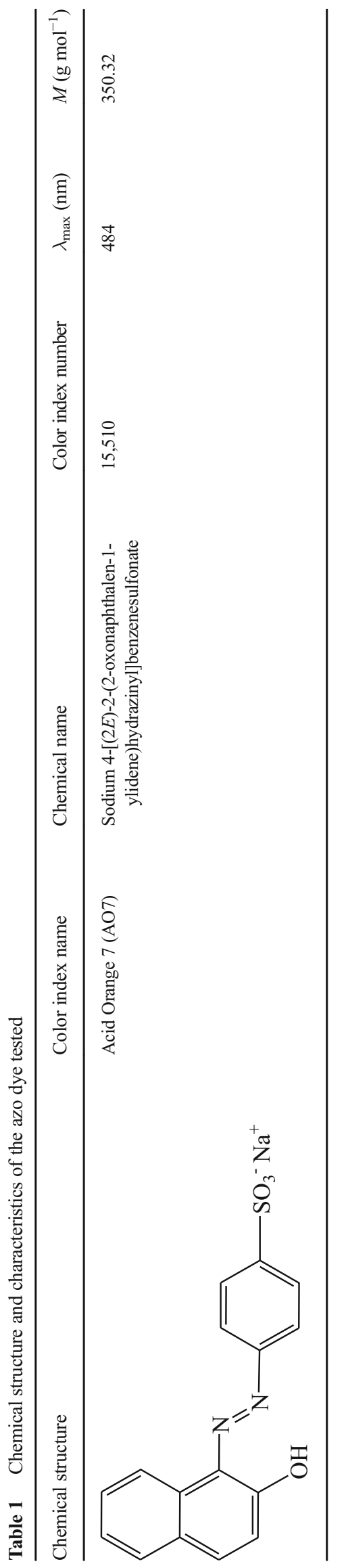

where $A_{0}$ and $A_{t}$ are the absorbance at initial time and time $t$, respectively, at $\lambda_{\max }=484 \mathrm{~nm}$.

The mineralization of the same solutions was followed from their total organic carbon (TOC) removal, measured on a Shimadzu TOC-VCSN analyzer. Aliquots of $50 \mu \mathrm{L}$ were injected into this system and reproducible TOC values with $\pm 1 \%$ accuracy were obtained. The energy consumption per unit TOC mass (EC) was obtained from Eq. (7) [27-29]:

$\mathrm{EC}(\mathrm{kWhkg})=\frac{1000 E_{\text {cell }} I t}{V \Delta(\mathrm{TOC})_{\exp }}$

where 1000 is a conversion factor $\left(\mathrm{mg} \mathrm{g}^{-1}\right), E_{\text {cell }}$ is the average potential difference of the cell (in V), $I$ is the applied current (A), $t$ is the electrolysis time $(\mathrm{h}), V$ is the solution volume (L), and $\Delta(\text { TOC })_{\exp }$ is the experimental TOC decay $\left(\mathrm{mg} \mathrm{L}^{-1}\right)$.

Considering the following theoretical mineralization reaction of $\mathrm{AO} 7$ anion to $\mathrm{CO}_{2}, \mathrm{SO}_{4}{ }^{2-}$, and $\mathrm{NH}_{4}{ }^{+}$as pre-eminent ion:

$$
\begin{aligned}
& \mathrm{C}_{16} \mathrm{H}_{11} \mathrm{~N}_{2} \mathrm{O}_{4} \mathrm{~S}^{-}+32 \mathrm{H}_{2} \mathrm{O} \rightarrow 16 \mathrm{CO}_{2}+2 \mathrm{NH}_{4}{ }^{+}+\mathrm{SO}_{4}{ }^{2-} \\
& +67 \mathrm{H}^{+}+68 \mathrm{e}^{-}
\end{aligned}
$$

the mineralization current efficiency (MCE) for each trial was estimated from Eq. (9) [28]:

$\operatorname{MCE}(\%)=\frac{n F V \Delta(\text { TOC })_{\exp }}{4.32 \times 10^{7} m I t} \times 100$

where $n$ is the number of electrons involved during AO7 mineralization (68 according to reaction (8)), $F$ is the Faraday constant $\left(96,487 \mathrm{C} \mathrm{mol}^{-1}\right), 4.32 \times 10^{7}$ is a factor for units homogenization (3600 s h $\mathrm{s}^{-1} \times 12,000 \mathrm{mg} \mathrm{mol}^{-1}$ ), and $m$ is the number of carbon atoms of AO7 (16 atoms).

For the optimized SPEF run, the AO7 concentration decay was followed by reversed-phase HPLC with a Waters $600 \mathrm{LC}$ fitted with a Spherisorb ODS2 $5 \mu \mathrm{m}, 150 \mathrm{~mm} \times 4.6 \mathrm{~mm}$, column at $35^{\circ} \mathrm{C}$ and coupled with a Waters 996 photodiode array detector set at $\lambda=310 \mathrm{~nm}$. Aliquots of $20 \mu \mathrm{L}$ were injected into the LC and a 30:70 (v/v) acetonitrile/water $(2.4 \mathrm{mM} n$ butylamine) mixture was eluted at $0.6 \mathrm{~mL} \mathrm{~min}^{-1}$ as mobile phase. The chromatograms displayed a peak for AO7 anion with a retention time $\left(t_{\mathrm{r}}\right)$ of $7.6 \mathrm{~min}$. The generated short-linear carboxylic acids were determined by ion-exclusion HPLC with the same LC fitted with a Bio-Rad Aminex HPX 87H, $300 \mathrm{~mm} \times 7.8 \mathrm{~mm}$, column at $35^{\circ} \mathrm{C}$, and the detector was selected at $\lambda=210 \mathrm{~nm}$. Aliquots of $20 \mu \mathrm{L}$ were injected into the $\mathrm{LC}$ and $4 \mathrm{mM} \mathrm{H}_{2} \mathrm{SO}_{4}$ at $0.6 \mathrm{~mL} \mathrm{~min}^{-1}$ was used as mobile phase. The chromatograms exhibited peaks related to oxalic $\left(t_{\mathrm{r}}=7.0 \mathrm{~min}\right)$, tartronic $\left(t_{\mathrm{r}}=7.9 \mathrm{~min}\right)$, maleic $\left(t_{\mathrm{r}}=8.2 \mathrm{~min}\right)$, tartaric $\left(t_{\mathrm{r}}=8.5 \mathrm{~min}\right)$, pyruvic $\left(t_{\mathrm{r}}=9.2 \mathrm{~min}\right)$, oxamic $(t-$ $\mathrm{r}=9.4 \mathrm{~min})$, formic $\left(t_{\mathrm{r}}=13.4 \mathrm{~min}\right)$, and fumaric $\left(t_{\mathrm{r}}=14.7 \mathrm{~min}\right)$. Released $\mathrm{NH}_{4}^{+}, \mathrm{NO}_{3}{ }^{-}$, and $\mathrm{SO}_{4}{ }^{2-}$ ions were quantified by ion 
chromatography following the method reported elsewhere [31].

\section{Solar Flow Plant}

The solar flow plant constructed by us for the treatment of $10 \mathrm{~L}$ of AO7 solutions in batch mode has been described before [28]. The solution introduced in the reservoir was recirculated through the system by a peristaltic pump. It passed through a flow meter and two heat exchangers to maintain a liquid flow rate of $200 \mathrm{~L} \mathrm{~h}^{-1}$ and $35^{\circ} \mathrm{C}$, respectively. Further, the effluent circulated through the electrochemical cell and, finally, through the solar CPC photoreactor before coming back to the reservoir. The electrochemical cell was a filter-press reactor equipped with a $100-\mathrm{cm}^{2} \mathrm{Pt}$ sheet $(99.99 \%$ purity) and a $100-\mathrm{cm}^{2}$ carbon-PTFE air-diffusion electrode for $\mathrm{H}_{2} \mathrm{O}_{2}$ electrogeneration from reaction (1), separated $1.2 \mathrm{~cm}$ by a PVC liquid compartment with a central window of $9.5 \mathrm{~cm} \times 9.5 \mathrm{~cm}\left(90.3 \mathrm{~cm}^{2}\right)$. The cathode was fed with compressed air at $4.5 \mathrm{~L} \mathrm{~min}^{-1}$ regulated with a back-pressure gauge. The constant current to the cell was provided by a Grelco GDL3020 power supply, which directly displayed the potential difference between electrodes. The solar CPC photoreactor had an irradiated volume of $1.57 \mathrm{~L}$, with a concentration factor of 1 and $0.4 \mathrm{~m}^{2}$ area. It was mounted in an aluminum frame on a platform tilted $41^{\circ}$ (local latitude) to better collect direct sun rays. Solar assays were made in sunny and clear days of summer 2015, and the UV irradiation intensity from 300 to $400 \mathrm{~nm}$ provided by sunlight was measured on a Kipp \& Zonen CUV 5 radiometer. Before performing the assays, the air-diffusion cathode was activated by polarizing $10 \mathrm{~L}$ of $0.05 \mathrm{M} \mathrm{Na}_{2} \mathrm{SO}_{4}$ at $\mathrm{pH} 3.0$ and $5 \mathrm{~A}$ for $240 \mathrm{~min}$.

\section{Experimental Design and Response Surface Methodology}

The optimum conditions for the decolorization and mineralization of AO7 solutions by SPEF was ascertained by CCRD and RSM. The time required for $90 \%$ color removal $\left(t_{90} \% \mathrm{CR}\right)$ was taken as a response because it determines the effluent decolorization before release. Besides, the time needed for $70 \%$ TOC removal $\left(t_{70} \%\right.$ TOC $)$ and the EC for $70 \%$ TOC removal $\left(\mathrm{EC}_{70} \% \mathrm{TOC}\right)$ were taken as responses because it has been corroborated that after attaining $70 \%$ of TOC removal, the aromatic by-products are completely removed, remaining only highly biodegradable short-linear aliphatic carboxylic and dicarboxylic acids. A current from 3.0 to $8.4 \mathrm{~A}, \mathrm{Fe}^{2+}$ content from 0.08 to $1.92 \mathrm{mg} \mathrm{L}^{-1}$, and dye concentration from 75 to $209 \mathrm{mg} \mathrm{L}^{-1}$ TOC were selected as independent variables, with five coded levels as $x_{i}=-1.68,-1,0,1$, and 1.68 , as shown in Table 2. The CCRD consisted of eight factorial points, six axial points, and three central points, in a total of 17 runs [49]. The relation between each response and the independent variables was given by the following secondorder model $[49,50]$ :

$Y=\beta_{0}+\sum_{i=1}^{k} \beta_{i} x_{i}+\sum_{i=1}^{k} \beta_{i i} x_{i}^{2}+\sum_{i=1}^{k} \sum_{i \# j=1}^{k} \beta_{i j} x_{i} x_{j}+\varepsilon$

where $Y$ is the response; $\beta_{0}$ is a constant coefficient; $\beta_{i}, \beta_{i i}$, and $\beta_{i j}$ are the coefficients for the linear, quadratic, and interaction effects, respectively; $x_{i}$ and $x_{j}$ are the coded levels for the independent variables; $k$ is the number of independent variables; and $\varepsilon$ is the random error.

The three replicates in the central point (runs 15 to 17 in Table 2) allowed estimating the pure error. The response surfaces $[35,36,49]$ were generated by a StatSoft Statistica v6 program. The resulting polynomial models were statistically validated by analysis of variance (ANOVA), with their statistical significances checked from $F$ test and their fit quality from $R^{2}$ coefficients.

\section{Results and Discussion}

\section{SPEF Degradation of AO7 Solutions}

Blank experiments made with $10 \mathrm{~L}$ of $\mathrm{AO} 7$ solutions under recirculation in the solar flow plant, but without current pass, did not evidence any color and TOC removals, indicating that the azo dye is not directly photolyzed by sunlight.

When SPEF was applied, the strong orange color of starting solutions lost intensity turning into a dark brown color that slowly became clearer up to colorless solutions. This suggests the gradual production of colored conjugated products slowly destroyed mainly by ${ }^{\circ} \mathrm{OH}$ formed in the bulk from Fenton's reaction (2) and in a smaller extent by $\mathrm{Pt}\left({ }^{\circ} \mathrm{OH}\right)$ produced from reaction $(5)[5,12,13]$. Since the solution $\mathrm{pH}$ dropped during electrolysis due to the production of acidic products like carboxylic acids, it was continuously regulated at $\mathrm{pH} 3.0$ by adding small volumes of $0.5 \mathrm{M} \mathrm{NaOH}$. The mineralization rate of $\mathrm{AO} 7$ solutions was much slower than its decolorization by the generation of more recalcitrant products, difficultly removed by hydroxyl radicals and sunlight. From this behavior, times related to $90 \%$ color and $70 \%$ TOC removals were taken to optimize the independent variables in CCRD for the decolorization and mineralization processes, respectively. The EC for $70 \%$ TOC removal was also chosen to minimize the energy consumption of SPEF. The observed responses for all coded levels checked are collected in Table 2. This table also shows that all runs always received a quite analogous average UV irradiation intensity between 30.2 and $32.4 \mathrm{~W} \mathrm{~m}^{-2}$. 
Table 2 Coded levels and real values for the CCRD and RSM analysis of the SPEF treatment of AO7 solutions in $0.05 \mathrm{M} \mathrm{Na}_{2} \mathrm{SO}_{4}$ at pH 3.0 and $35^{\circ} \mathrm{C}$ using a $10-\mathrm{L}$ solar flow plant

\begin{tabular}{|c|c|c|c|c|c|c|c|c|c|c|}
\hline \multirow[t]{2}{*}{ Run } & \multicolumn{3}{|c|}{ Coded levels } & \multicolumn{3}{|c|}{ Real values } & \multicolumn{3}{|c|}{ Observed responses } & \multirow[b]{2}{*}{$\begin{array}{l}\mathrm{UV}^{\mathrm{d}} \\
\left(\mathrm{W} \mathrm{m}^{-2}\right)\end{array}$} \\
\hline & $x_{1}$ & $x_{2}$ & $x_{3}$ & $X_{1}^{\mathrm{a}}$ & $X_{2}^{\mathrm{b}}$ & $X_{3}^{\mathrm{c}}$ & $\begin{array}{l}t_{90} \% \mathrm{CR} \\
(\mathrm{min})\end{array}$ & $\begin{array}{l}t_{70} \% \mathrm{TOC} \\
(\mathrm{min})\end{array}$ & $\begin{array}{l}\mathrm{EC}_{70} \% \mathrm{TOC} \\
\left(\mathrm{kWh} \mathrm{kg}^{-1} \mathrm{TOC}\right)\end{array}$ & \\
\hline 1 & -1 & -1 & -1 & 3.0 & 0.45 & 75 & 68.9 & 195 & 122.2 & 30.2 \\
\hline 2 & 1 & -1 & -1 & 7.0 & 0.45 & 75 & 43.2 & 90 & 167.5 & 32.4 \\
\hline 3 & -1 & 1 & -1 & 3.0 & 1.55 & 75 & 89.0 & 188 & 91.6 & 30.4 \\
\hline 4 & 1 & 1 & -1 & 7.0 & 1.55 & 75 & 71.5 & 103 & 201.2 & 31.2 \\
\hline 5 & -1 & -1 & 1 & 3.0 & 0.45 & 150 & 159.5 & 310 & 75.7 & 32.1 \\
\hline 6 & 1 & -1 & 1 & 7.0 & 0.45 & 150 & 64.7 & 153 & 130.8 & 31.3 \\
\hline 7 & -1 & 1 & 1 & 3.0 & 1.55 & 150 & 216.5 & 450 & 109.4 & 30.2 \\
\hline 8 & 1 & 1 & 1 & 7.0 & 1.55 & 150 & 140.9 & 282 & 221.0 & 31.1 \\
\hline 9 & -1.68 & 0 & 0 & 1.6 & 1.00 & 125 & 136.3 & 314 & 34.2 & 30.4 \\
\hline 10 & 1.68 & 0 & 0 & 8.4 & 1.00 & 125 & 52.2 & 107 & 113.4 & 30.7 \\
\hline 11 & 0 & -1.68 & 0 & 5.0 & 0.08 & 125 & 138.0 & 228 & 155.0 & 31.8 \\
\hline 12 & 0 & 1.68 & 0 & 5.0 & 1.92 & 125 & 168.7 & 309 & 224.2 & 32.5 \\
\hline 13 & 0 & 0 & -1.68 & 5.0 & 1.00 & 41 & 52.2 & 67 & 153.5 & 30.5 \\
\hline 14 & 0 & 0 & 1.68 & 5.0 & 1.00 & 209 & 153.3 & 339 & 157.8 & 31.4 \\
\hline 15 & 0 & 0 & 0 & 5.0 & 1.00 & 125 & 108.14 & 177 & 134.2 & 30.6 \\
\hline 16 & 0 & 0 & 0 & 5.0 & 1.00 & 125 & 115.7 & 183 & 141.4 & 32.2 \\
\hline 17 & 0 & 0 & 0 & 5.0 & 1.00 & 125 & 113.0 & 182 & 139.0 & 30.7 \\
\hline
\end{tabular}

${ }^{\mathrm{a}}$ Current $(\mathrm{A})$

${ }^{\mathrm{b}} \mathrm{Fe}^{2+}$ concentration $(\mathrm{mM})$

${ }^{\mathrm{c}}$ Initial dye concentration (mg L ${ }^{-1}$ TOC)

${ }^{\mathrm{d}}$ Average UV irradiation intensity supplied by sunlight during the SPEF trial

\section{Effect of Independent Experimental Variables on the SPEF Process}

Analysis of the observed responses given in Table 1 using Eq. (10) led to the following second-order models with $95 \%$ confidence level:

$$
\begin{aligned}
t_{90 \% \mathrm{CR}}=112.9-25.99 x_{1}+17.06 x_{2}+35.08 x_{3}-8.64 x_{1}{ }^{2} \\
\quad+12.23 x_{2}{ }^{2}-5.64 x_{3}{ }^{2}-3.42 x_{1} x_{2}-15.9 x_{1} x_{3}+10.62 x_{2} x_{3}
\end{aligned}
$$

$t_{70 \% \mathrm{TOC}}=181.2-63.2 x_{1}+30.1 x_{2}+78.8 x_{3}+8.6 x_{1}{ }^{2}+29.1 x_{2}{ }^{2}+5.9 x_{3}{ }^{2}+1.1 x_{1} x_{2}$

$-16.8 x_{1} x_{3}+32.9 x_{2} x_{3}$

$\mathrm{EC}_{70 \% \mathrm{TOC}}=138.2+33.3 x_{1}+17.8 x_{2}-2.8 x_{3}-22.7 x_{1}{ }^{2}+18.2 x_{2}{ }^{2}+6.2 x_{3}{ }^{2}+15.1 x_{1} x_{2}$

$+1.5 x_{1} x_{3}+15.1 x_{2} x_{3}$ 
where $x_{1}, x_{2}$, and $x_{3}$ are the current, $\mathrm{Fe}^{2+}$ concentration, and azo dye concentration, respectively. Note that Eqs. (11)-(13) only include the most significant terms obtained from ANOVA. Figure 1 shows the response surfaces generated from the above equations.

The great negative contribution of $x_{1}$ in Eqs. (11) and (12) indicates shorter times for $90 \%$ decolorization and $70 \%$ mineralization when current increased, as shown in Fig. 1a, b, d, e. The negative coefficient of $x_{1}^{2}$ in Eq. (11) also favored the color removal as current grew. Nevertheless, the positive coefficient for the same parameter in Eq. (12) yielded the opposite trend, although its low value compared with that of $x_{1}$ slightly decelerated the drop of $t_{70} \% \mathrm{TOC}$ at high current (Fig. 1d, e). This suggests the production of more quantities of oxidizing hydroxyl radicals with increasing current by acceleration of electrode reactions (5) and (1), originating more $\mathrm{Pt}\left({ }^{\circ} \mathrm{OH}\right)$ and $\mathrm{H}_{2} \mathrm{O}_{2}$, respectively, which enhances the generation of ${ }^{\circ} \mathrm{OH}$ from Fenton's reaction (2) $[5,28,31]$. The faster oxidation of products leads to higher amounts of photoactive products that are more quickly destroyed upon solar irradiation, thus upgrading mineralization and diminishing $t_{70} \%$ TOC [31]. However, the growth in current caused a variable influence on $\mathrm{EC}_{70} \% \mathrm{TOC}$ by the high positive contribution of $x_{1}$ and the relatively smaller negative coefficient of $x_{1}{ }^{2}$ in Eq. (13), predominating at low and high current, respectively. Figure $1 \mathrm{~g}$, h evidences the compensation of both contributions at about 6-7 A giving a a

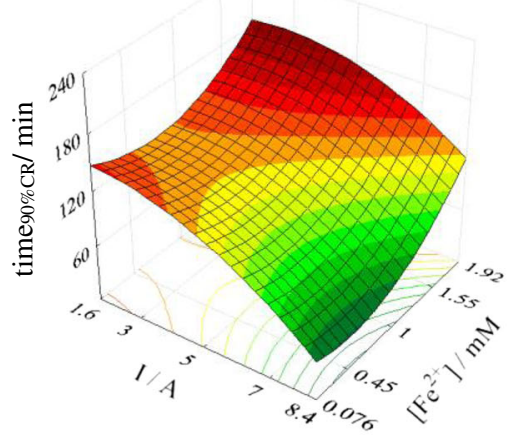

d

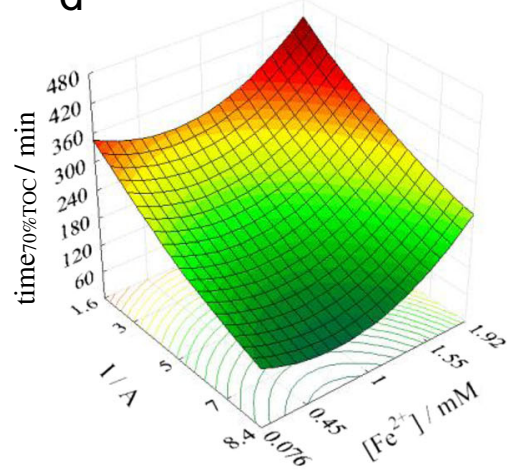

g

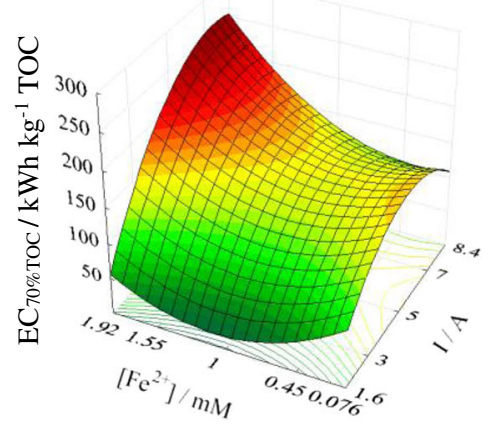

b

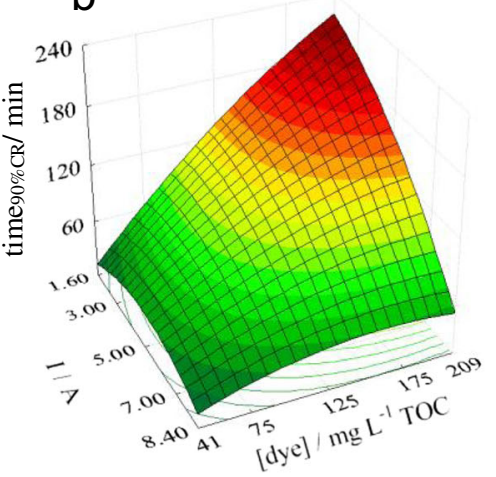

e

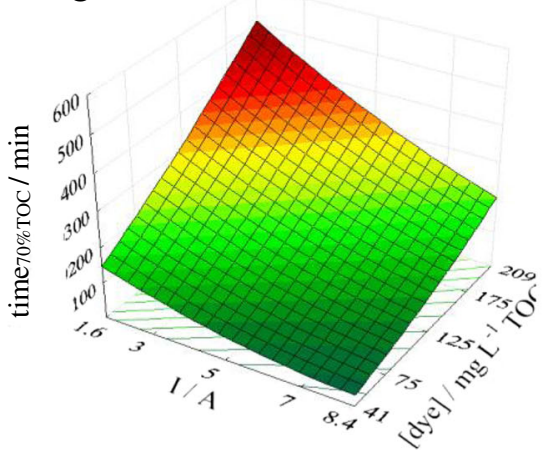

h

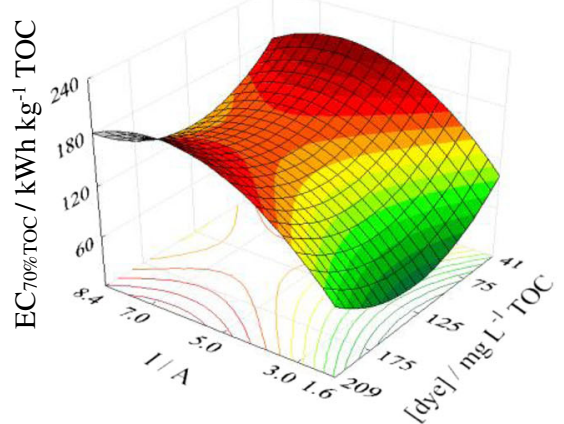

C

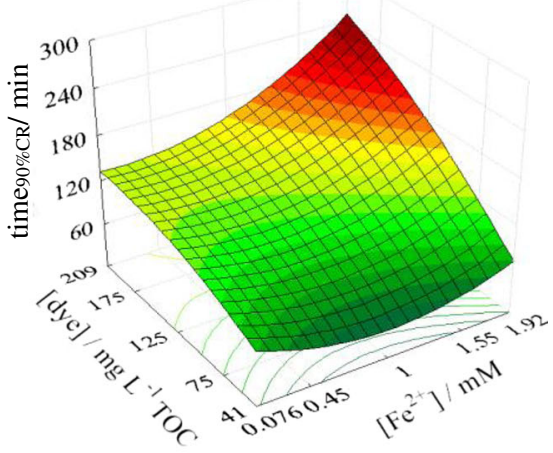

$\mathrm{f}$

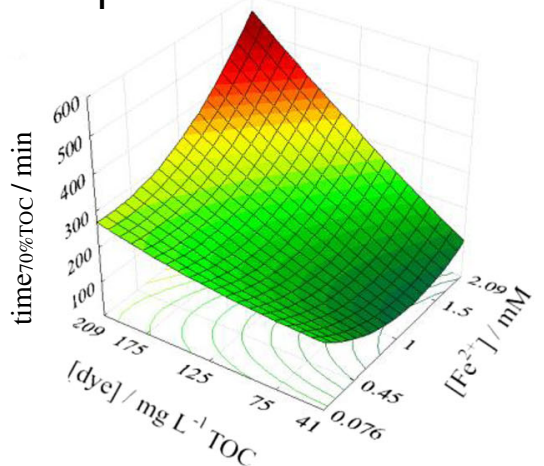

i

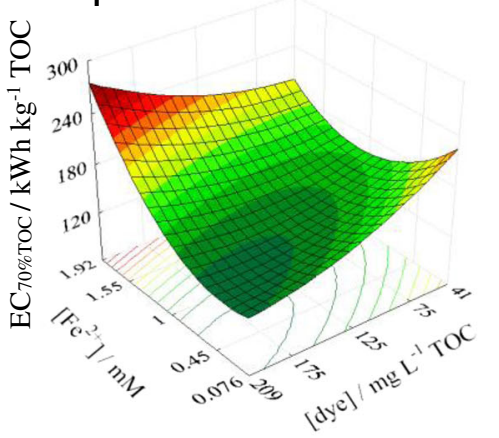

Fig. 1 CCRD response surfaces after the SPEF degradation of $10 \mathrm{~L}$ of Acid Orange 7 (AO7) solutions in $0.05 \mathrm{M} \mathrm{Na}_{2} \mathrm{SO}_{4}$ at $\mathrm{pH} 3.0$ and $35^{\circ} \mathrm{C}$ using a solar flow plant at a liquid flow rate of $200 \mathrm{~L} \mathrm{~h}^{-1}$. a-c Time required for $90 \%$ color removal, $\mathbf{d}-\mathbf{f}$ time needed for $70 \%$ total

organic carbon (TOC) removal, and $\mathbf{g}-\mathbf{i}$ energy consumption per unit TOC mass (EC) for $70 \%$ TOC removal as a function of applied current and dye and $\mathrm{Fe}^{2+}$ concentrations as independent variables 
maximum $\mathrm{EC}_{70} \% \mathrm{TOC}$ value. At higher current, the decay of this response can be related to a much more efficient TOC removal by the quicker photolysis of higher amounts of products formed upon the potent action of sunlight.

Equations (11)-(13) also point to a notable effect of $\mathrm{Fe}^{2+}$ concentration over all responses, owing to the positive contributions of $x_{2}$ and $x_{2}{ }^{2}$. The response surfaces (Fig. 1a, c, d, f, g, i) reflect the existence of minimum values of $t_{90} \% \mathrm{CR}, t_{70} \% \mathrm{TOC}$, and $\mathrm{EC}_{70} \% \mathrm{TOC}$ at about $0.75 \mathrm{mM} \mathrm{Fe}^{2+}$. This behavior can be related to the competence of Fenton's reaction (2) to produce 'OH in the bulk with the consumption of this radical by $\mathrm{Fe}^{2+}$ through reaction (14) [28]:

$$
\mathrm{Fe}^{2+}+{ }^{\circ} \mathrm{OH} \rightarrow \mathrm{Fe}^{3+}+\mathrm{OH}^{-}
$$

The lower responses when the $\mathrm{Fe}^{2+}$ content grew from 0.08 to $0.75 \mathrm{mM}$ can be associated with the gradual acceleration of Fenton's reaction (2) by the presence of more $\mathrm{Fe}^{2+}$ in the effluent. The greater generation of ${ }^{\circ} \mathrm{OH}$ enhanced the decolorization and mineralization of AO7, diminishing the energy consumption as well. In contrast, the excess of added $\mathrm{Fe}^{2+}$ from 0.75 to $1.92 \mathrm{mM}$ caused a rapid and progressive acceleration of reaction (14), dropping the quantity of ${ }^{\circ} \mathrm{OH}$ able to oxidize organics and, consequently, prolonging $t_{90} \% \mathrm{CR}$ and $t_{70} \%$ TOC and upgrading $\mathrm{EC}_{70} \% \mathrm{TOC}$.

The high positive contributions of $x_{3}$ in Eqs. (11) and (12) indicate a gradual increase of $t_{90} \% \mathrm{CR}$ and $t_{70} \% \mathrm{TOC}$ with increasing azo dye concentration. This can be observed in the response surfaces of Fig. 1b, c, e, f, at constant current and $\mathrm{Fe}^{2+}$ content, and can be related to the reaction of lower percentages of color and TOC removals with similar amounts of hydroxyl radicals. However, the low negative coefficient of $x_{3}$ and the slightly higher positive coefficient of $x_{3}{ }^{2}$ gave lower $\mathrm{EC}_{70} \% \mathrm{TOC}$ for azo dye contents $>150 \mathrm{mg} \mathrm{L}^{-1}$ TOC, as clearly shown in Fig. 1h, i. This opposite tendency to the other two increasing responses is due to the gradual destruction of more quantity of TOC. The oxidation ability of the SPEF process is then progressively upgraded because more $\mathrm{Pt}\left({ }^{\circ} \mathrm{OH}\right)$ and ${ }^{\circ} \mathrm{OH}$ are able to oxidize organics, feasible by the deceleration of waste reactions of both radicals. Examples are the oxidation of $\mathrm{Pt}(\mathrm{OH})$ to gas $\mathrm{O}_{2}$ from reaction (15) and the consumption of - OH by $\mathrm{Fe}^{2+}$ and generated $\mathrm{H}_{2} \mathrm{O}_{2}$ from reactions (14) and (16), respectively $[5,12,15]$.

$$
\begin{aligned}
& 2 \mathrm{Pt}\left({ }^{\circ} \mathrm{OH}\right) \rightarrow 2 \mathrm{Pt}+\mathrm{O}_{2(\mathrm{~g})}+2 \mathrm{H}^{+}+2 \mathrm{e}^{-} \\
& \mathrm{H}_{2} \mathrm{O}_{2}+{ }^{\circ} \mathrm{OH} \rightarrow \mathrm{HO}_{2}{ }^{\cdot}+\mathrm{H}_{2} \mathrm{O}
\end{aligned}
$$

\section{Validation of the Polynomial Models}

The statistical validation of the polynomial regressions of Eqs. (11)-(13) was made by the Fisher distribution ( $F$ test) of ANOVA. The significance of the models was assessed from the ratio of the mean squares of regressions with residuals (difference between the observed and predicted values). The adjustment of the same models was evaluated from the ratio of the mean squares of lack of fit with pure error. The $F$ ratio determined for the models was 23.15 for $t_{90} \% \mathrm{CR}, 166.59$ for $t_{70} \% \mathrm{TOC}$, and 24.49 for $\mathrm{EC}_{70} \% \mathrm{TOC}$, higher than 3.29 theoretically established for $95 \%$ confidence level [36], confirming the statistical significance of the obtained regressions. The $F$ ratio obtained for the lack of fit of the models was 16.59 for $t_{90} \% \mathrm{CR}$, 15.17 for $t_{70} \% \mathrm{TOC}$, and 17.15 for $\mathrm{EC}_{70} \% \mathrm{TOC}$, values smaller than 19.30 tabulated for a $95 \%$ confidence level $[35,36]$, evidencing a lack of fit of the developed regressions. Figure 2a-c depicts excellent linear straights between the predicted and observed responses of $t_{90} \% \mathrm{CR}, t_{70} \% \mathrm{TOC}$, and $\mathrm{EC}_{70} \% \mathrm{TOC}$, respectively, with corresponding $R^{2}$ values of $0.978,0.995$, and 0.979 . These good coefficients, close to unity, also corroborate the statistical significance of Eqs. (11)-(13).
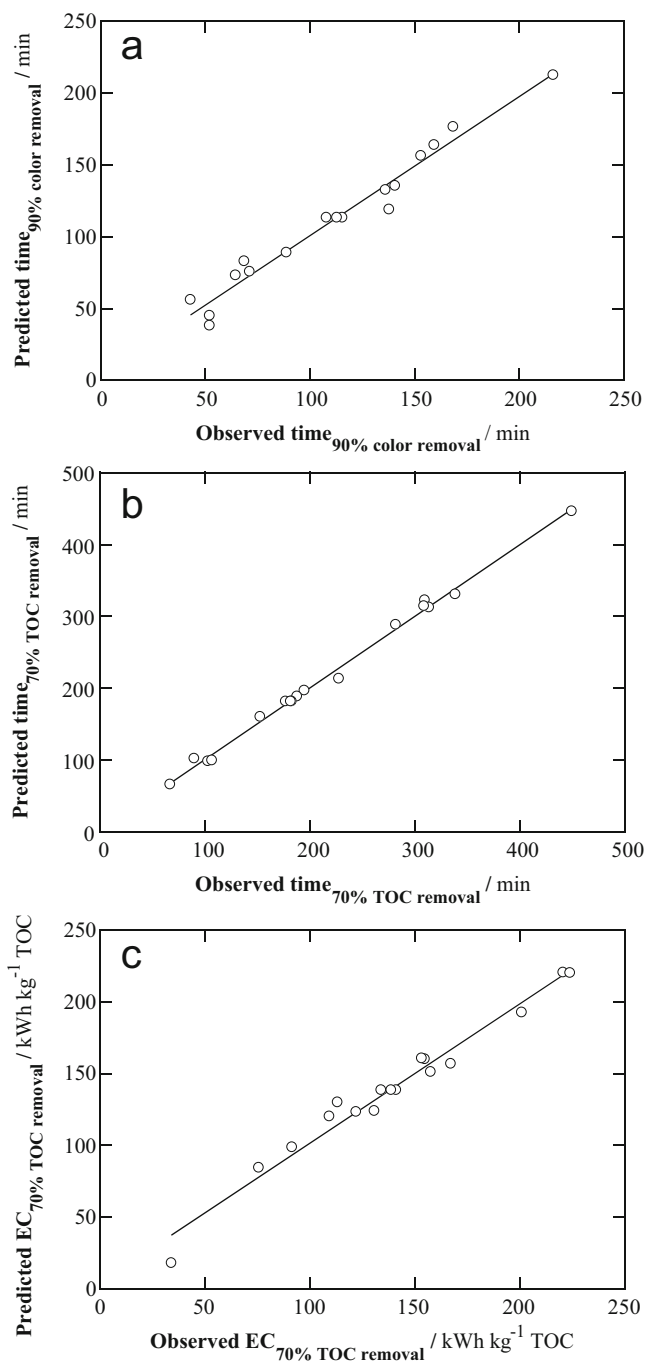

Fig. 2 Predicted values determined for a time required for $90 \%$ color removal from Eq. (11), b time needed for $70 \%$ TOC from Eq. (12), and c EC for $70 \%$ TOC removal from Eq. (13) vs. the observed values 
The residual-observed plots for these three regressions are presented in Fig. 3a-c, respectively. A random distribution of the residuals around the mean value of zero can be always observed as a result of the good agreement of the regressions without systematic errors. The statistical values determined from ANOVA and collected in Table 3 demonstrate the insignificance of the lack of fit with $p$ values $>0.05$ for all the three responses. The coefficient of determination $R^{2}$ is the parameter to determine the overall efficiency of model prediction, showing high values $(>0.98)$, and hence, ensuring good correlations between observed values and model-predicted values is ensured. For the three developed models, $R^{2}$ adjusted and $R_{\text {predicted }}^{2}$ do not differ considerably. Table 3 also shows an adequate precision (AP) $>10$ in all cases, evidencing the good models developed, and an excellent reproducibility assessed by low coefficient of variance $(\mathrm{CV})$ values below $5 \%$.
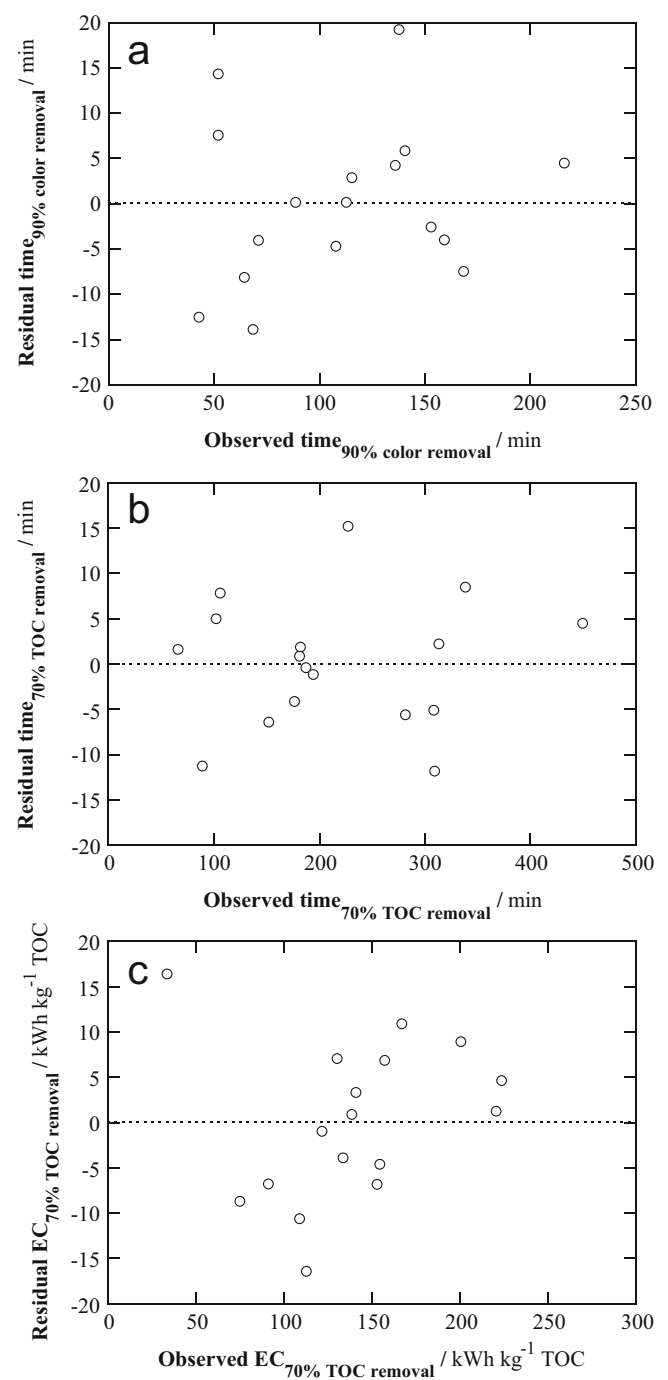

Fig. 3 Residual values calculated as the difference between the observed and predicted ones for a time required for $90 \%$ color removal, b time needed for $70 \%$ TOC removal, and $\mathbf{c} \mathrm{EC}$ for $70 \%$ TOC removal as a function of the observed ones

\section{Optimization of the SPEF Process of AO7}

The optimum conditions for the SPEF treatment of AO7 solutions were determined from the RSM results considering the lower times for color and TOC removals with the smaller energy consumption, i.e., the maximum effectiveness of oxidation with hydroxyl radicals and sunlight. Acceptable responses were found for a current of $4.0 \mathrm{~A}, 0.75 \mathrm{mM} \mathrm{Fe}{ }^{2+}$, and azo dye content of $150 \mathrm{mg} \mathrm{L}^{-1} \mathrm{TOC}$, which were selected as the best experimental conditions for the SPEF process. It should be highlighted that under these operational conditions, the models predicted values of $t_{90} \% \mathrm{CR}=158.9 \mathrm{~min}$, $t_{70} \% \mathrm{TOC}=290 \mathrm{~min}$, and $\mathrm{EC}_{70} \% \mathrm{TOC}=148 \mathrm{kWh} \mathrm{kg}^{-1} \mathrm{TOC}$, which are quite similar to the experimental values of $t_{90} \% \mathrm{CR}=160 \mathrm{~min}, t_{70} \%$ тоC $=296 \mathrm{~min}$, and $\mathrm{EC}_{70} \% \mathrm{TOC}=150 \mathrm{kWh} \mathrm{kg}^{-1} \mathrm{TOC}$, thereby demonstrating a good agreement with the RSM model defined.

Figure $4 \mathrm{a}$ highlights that the decolorization efficiency underwent a continuous, but slow, growth with prolonging electrolysis time, reaching total decolorization after $300 \mathrm{~min}$. As stated above, Eq. (11) predicted a $t_{90 \% \mathrm{CR}}=158.9 \mathrm{~min}$, very close to $160 \mathrm{~min}$ experimentally obtained, pointing to a good agreement of the regression developed by RSM. However, a very different behavior from AO7 decay was found by reversed-phase HPLC, since the azo dye disappeared in only $80 \mathrm{~min}$, as shown in Fig. 4b. The much quicker AO7 removal compared to its decolorization evidences that its fast oxidation with $\mathrm{Pt}\left({ }^{\circ} \mathrm{OH}\right)$ and mainly ${ }^{\circ} \mathrm{OH}$ yields large amounts of colored aromatic products, which absorb at the same $\lambda_{\max }=484 \mathrm{~nm}$ and are much more slowly destroyed by hydroxyl radicals with insignificant participation of sunlight [28, 31]. Moreover, AO7 obeyed a pseudo-first-order kinetics reaction, as shown in the inset panel of Fig. 4b. From this analysis, an apparent rate constant of $0.043 \mathrm{~min}^{-1}$ with $R^{2}=0.991$ was found. This suggests that the azo dye reacts with a low and steady concentration of hydroxyl radicals, at least in the starting of the SPEF run.

Figure 5a shows an $\mathrm{S}$ shape for TOC decay, with a long delay time close to $210 \mathrm{~min}$ where it was only reduced by $13 \%$. At a longer time, TOC was very rapidly removed until attaining $96 \%$ decay at $360 \mathrm{~min}$. This tendency agrees with the large decolorization suffered by the effluent with the formation of colored products that are slowly destroyed by $\mathrm{Pt}\left({ }^{\circ} \mathrm{OH}\right)$ and ${ }^{\circ} \mathrm{OH}$ from 80 to $300 \mathrm{~min}$ (Fig. 4a, b). The smaller molecules originated from these colored products are much more rapidly removed under the synergistic action of such generated hydroxyl radicals and sunlight, causing a quick TOC reduction up to almost total mineralization. Note that a time of 296 min was required for $70 \%$ TOC removal, close to 290 min obtained from Eq. (12), confirming its good fit to predict this response.

As expected from the $\mathrm{S}$ shape of TOC abatement, very low MCE values and very high EC values were determined up to 
Table 3 Analysis of variance for each response optimized

\begin{tabular}{|c|c|c|c|c|c|c|}
\hline Source & Sum of squares & $D F$ & Mean square & $F$ value & $p$ & \\
\hline \multicolumn{7}{|c|}{ Decolorization at $t_{90} \% \mathrm{CR}$} \\
\hline Model & $37,110.1$ & 9 & 4123.3 & 23.2 & 0.0002 & Significant \\
\hline Residual & 1246.9 & 7 & 178.1 & & & \\
\hline Lack of fit & 1217.5 & 5 & 245.5 & 16.6 & 0.0578 & Not significant \\
\hline Pure error & 29.3 & 2 & 14.7 & & & \\
\hline$R_{\text {adjusted }}^{2}=0.9992$ & $R_{\text {predicted }}^{2}=0.967$ & & $\mathrm{AP}=14.7$ & $\mathrm{CV}=3.54 \%$ & & \\
\hline \multicolumn{7}{|c|}{ Mineralization at $t_{70} \% \mathrm{TOC}$} \\
\hline Model & $172,355.0$ & 9 & $19,151.0$ & 166.6 & $<0.0001$ & Significant \\
\hline Residual & 804.7 & 7 & 114.9 & & & \\
\hline Lack of fit & 784.0 & 5 & 156.8 & 15.2 & 0.0630 & Not significant \\
\hline Pure error & 20.7 & 2 & 10.3 & & & \\
\hline$R_{\text {adjusted }}^{2}=0.9998$ & $R_{\text {predicted }}^{2}=0.995$ & & $\mathrm{AP}=10.3$ & $\mathrm{CV}=2.78 \%$ & & \\
\hline \multicolumn{7}{|c|}{ Energy consumption at $\mathrm{EC}_{70} \% \mathrm{TOC}$} \\
\hline Model & $37,441.0$ & 9 & 4160.1 & 24.5 & 0.0001 & Significant \\
\hline Residual & 1188.8 & 7 & 169.8 & & & \\
\hline Lack of fit & 1161.8 & 5 & 232.4 & 17.2 & 0.0560 & Not significant \\
\hline Pure error & 27.1 & 2 & 13.5 & & & \\
\hline$R_{\text {adjusted }}^{2}=0.9992$ & $R_{\text {predicted }}^{2}=0.967$ & & $\mathrm{AP}=14.7$ & $\mathrm{CV}=3.54 \%$ & & \\
\hline
\end{tabular}

210 min of SPEF. Figure 5b depicts the gradual growth in current efficiency by the acceleration of mineralization as
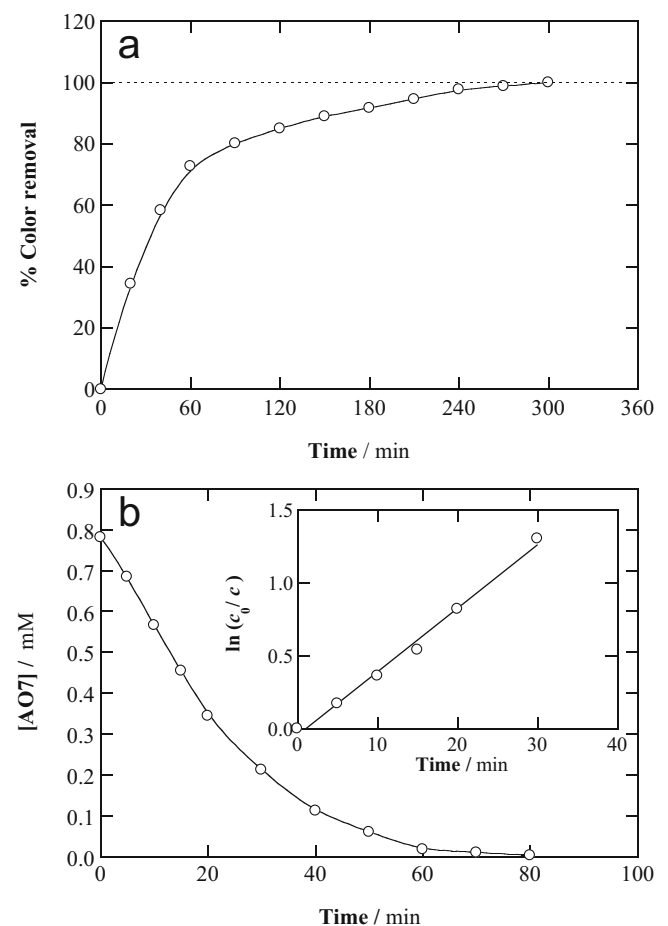

Fig. 4 a Percentage of color removal and b AO7 concentration decay with electrolysis time for the optimum treatment found by RSM of $10 \mathrm{~L}$ of a $0.781-\mathrm{mM}\left(150 \mathrm{mg} \mathrm{L}^{-1} \mathrm{TOC}\right) \mathrm{AO} 7$ solution in $0.05 \mathrm{M} \mathrm{Na}_{2} \mathrm{SO}_{4}$ with $0.75 \mathrm{mM} \mathrm{Fe}^{2+}$ at $\mathrm{pH} 3.0$ and $35^{\circ} \mathrm{C}$ by SPEF with a solar flow plant at 4.0 A and liquid flow rate of $200 \mathrm{~L} \mathrm{~h}^{-1}$ the intermediates are transformed into more easily oxidizable products. The MCE value grew from $13 \%$ at 210 min to $57 \%$ at the end of the run, when an almost total mineralization with $96 \%$ TOC reduction was achieved. Similarly, Fig. 5c shows the progressive drop of EC with prolonging electrolysis. Its value decayed from $580 \mathrm{kWh} \mathrm{kg}^{-1}$ TOC at $210 \mathrm{~min}$ to $133 \mathrm{kWh} \mathrm{kg}^{-1} \mathrm{TOC}$ at $360 \mathrm{~min}$. For $70 \%$ TOC removal, $150 \mathrm{kWh} \mathrm{kg}^{-1}$ TOC was experimentally found, similar to $148 \mathrm{kWh} \mathrm{kg}^{-1}$ TOC expected from Eq. (13), indicating the good agreement of this equation to describe this parameter.

\section{Evolution of Short-Linear Carboxylic Acids and Released Inorganic Ions}

Ion-exclusion chromatograms of the above treated azo dye solution displayed peaks related to maleic, fumaric, tartaric, pyruvic, tartronic, oxamic, oxalic, and formic acids. The five former acids are originated from the breaking of the benzenic and naphthalenic rings of aromatic intermediates, further being oxidized to oxalic and formic acids [26-31]. The degradation of intermediates with a $\mathrm{NH}_{2}$ group can yield oxamic acid. Oxalic, formic, and oxamic acids are directly mineralized to $\mathrm{CO}_{2}[5,12]$. It is expected that all acids form $\mathrm{Fe}$ (III)-carboxylate complexes due to the production of $\mathrm{Fe}^{3+}$ in a large extent from Fenton's reaction (2) under the SPEF conditions tested $[3,5,31]$. These complexes are very stable in front of the attack of hydroxyl radicals, and most of them can be photolyzed by UV light of sunlight irradiation via reaction (4). 


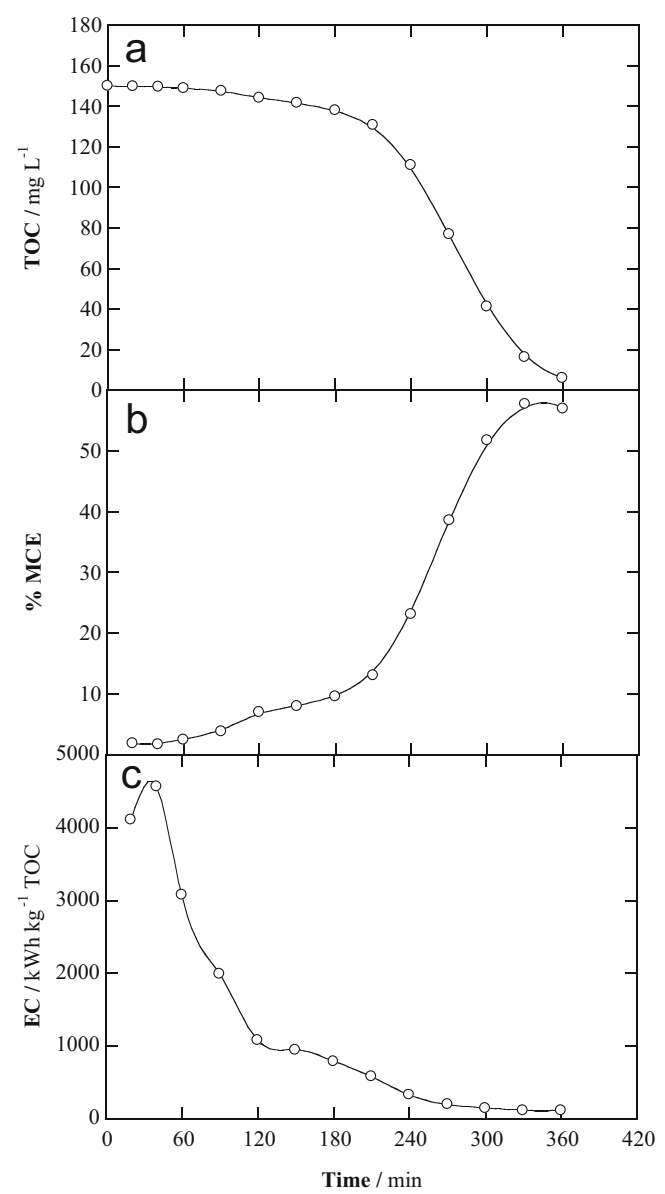

Fig. 5 a TOC decay and changes of $\mathbf{b}$ mineralization current efficiency and $\mathbf{c}$ EC with electrolysis time for the optimized SPEF run of Fig. 4

Figure 6a illustrates a low accumulation of maleic, fumaric, and pyruvic acids during the optimized SPEF process. While $\mathrm{Fe}$ (III)-maleate and $\mathrm{Fe}$ (III)-fumarate complexes only persisted for 150 min because of their quick photo-oxidation by sunlight, Fe(III)-fumarate species were more slowly photolyzed and completely removed at the end of treatment. In contrast, Fig. 6b shows a much larger accumulation of tartaric, tartronic, oxalic, oxamic, and formic acids starting from 120 to 180 min of electrolysis, just when TOC began to be strongly reduced due to the fast mineralization of intermediates (Fig. 5a). The Fe(III) complexes of the four former acids were rapidly photodecomposed until attaining final contents $<3 \mathrm{mg} \mathrm{L}^{-1}$, but the photo-oxidation of $\mathrm{Fe}$ (III)-formate species was so slow that $16 \mathrm{mg} \mathrm{L}^{-1}$ of formic acid remained in the final solution. A mass balance at the end of the optimized SPEF run points to $6 \mathrm{mg} \mathrm{L}^{-1}$ of TOC related to all final acids, in agreement with the experimental TOC of the resulting solution (see Fig. 5a). The final effluent was then only composed of a mixture of final short-linear carboxylic acid, whose persistence, pre-eminently of formic acid, impedes its total mineralization.

It is well-known that the $\mathrm{S}$ atoms of azo dyes with $-\mathrm{SO}_{3}{ }^{-}$ groups, like $\mathrm{AO} 7$, are released as $\mathrm{SO}_{4}{ }^{2-}[3,28,31,33]$ by
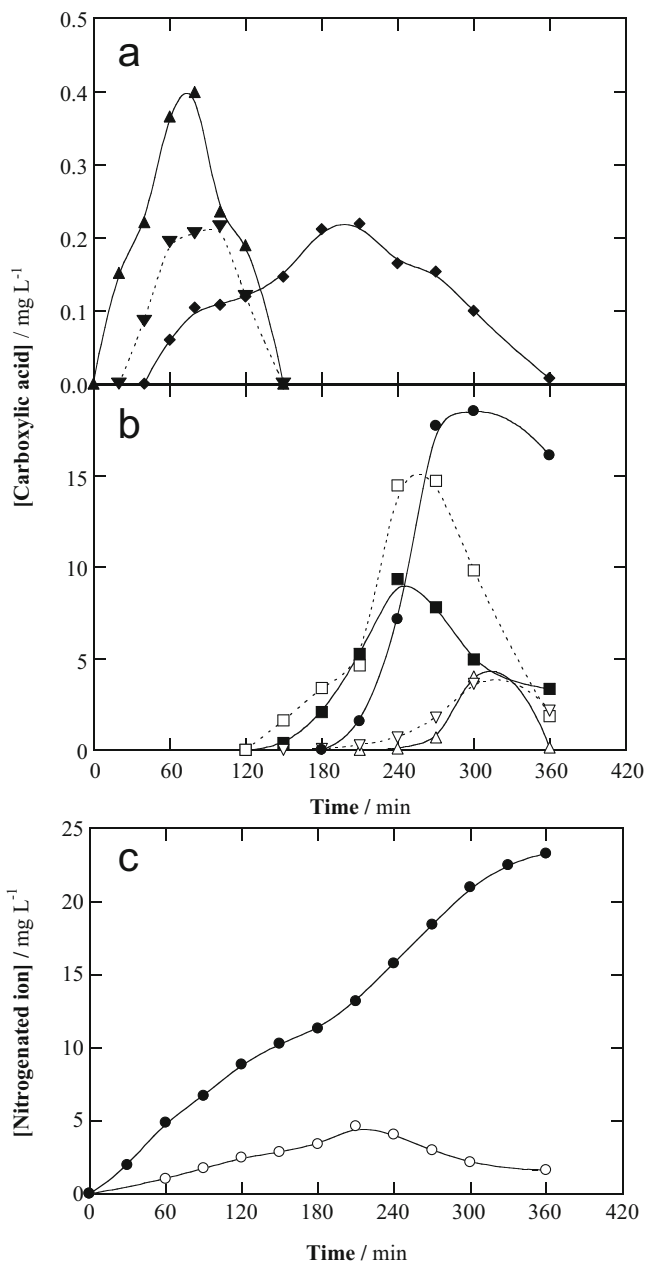

Fig. 6 Evolution of the concentration of a maleic (filled inverted triangle), pyruvic (filled diamond), and fumaric acids (filled triangle) and $\mathbf{b}$ tartaric (open triangle), tartronic (open square), oxamic (open inverted triangle), oxalic (filled square), and formic acids (filled circle) detected during the optimized SPEF trial of Fig. 4. $\mathbf{c}$ Time course of $\mathrm{NH}_{4}{ }^{+}$ (filled circle) and $\mathrm{NO}_{3}^{-}$(open circle) ions detected during the same assay

EAOPs, as stated in reaction (8). The evolution of $\mathrm{NH}_{4}{ }^{+}$ and $\mathrm{NO}_{3}{ }^{-}$ions coming from the $\mathrm{N}$ atoms $\left(22.1 \mathrm{mg} \mathrm{L}^{-1}\right)$ of the azo dye during the optimized SPEF was followed by ion chromatography. No other nitrogenated ions like $\mathrm{NO}_{2}{ }^{-}$ were detected using this technique. Figure $6 \mathrm{c}$ reveals a continuous release of $\mathrm{NH}_{4}{ }^{+}$during the process to reach a concentration of $23.3 \mathrm{mg} \mathrm{L}^{-1}(82.1 \%$ of initial N). This evidences that $\mathrm{NH}_{4}{ }^{+}$is the pre-eminent ion originated during SPEF, as proposed in the theoretical mineralization reaction (9) of $\mathrm{AO} 7$ anion. In contrast, Fig. 6c also shows a poor production of $\mathrm{NO}_{3}{ }^{-}$, with a maximal of $4.6 \mathrm{mg} \mathrm{L}^{-1}$ at $210 \mathrm{~min}$ that is further reduced to $1.6 \mathrm{mg} \mathrm{L}^{-1}(1.6 \%$ of initial $\mathrm{N}$ ). This surprising phenomenon has been observed for the SPEF treatment of other dyes [28, 32], being associated with the reduction of $\mathrm{NO}_{3}{ }^{-}$by intermediates upon activation with solar irradiation to give volatile species such as $\mathrm{N}_{2}$ and/or $\mathrm{N}_{x} \mathrm{O}_{y}$. 


\section{Conclusions}

The SPEF process of $\mathrm{AO} 7$ solutions in $0.05 \mathrm{M} \mathrm{Na}_{2} \mathrm{SO}_{4}$ of $\mathrm{pH}$ 3.0 can be optimized from the application of a CCRD coupled to RSM. Experiments were carried out with a 10-L solar flow plant equipped with a Pt/air-diffusion reactor and a solar CPC photoreactor operating under an average UV irradiation intensity near $31 \mathrm{~W} \mathrm{~m}^{-2}$. The optimum variables were $4.0 \mathrm{~A}$, $0.75 \mathrm{mM} \mathrm{Fe}^{2+}$, and $150 \mathrm{mg} \mathrm{L}^{-1}$ TOC of azo dye, determined for $90 \%$ decolorization and $70 \%$ mineralization. Under these conditions, total decolorization was achieved in $300 \mathrm{~min}$, whereas $\mathrm{AO} 7$ was removed in only $80 \mathrm{~min}$, indicating the formation of large amounts of colored aromatic products. Moreover, TOC was reduced by $96 \%$ in 360 min with $64 \%$ mineralization current efficiency and $133 \mathrm{kWh} \mathrm{kg}^{-1}$ TOC energy consumption The polynomial models developed by RSM predicted adequately the observed experimental data. The final treated solution contained a mixture of short-linear carboxylic acids like tartronic, oxalic, oxamic, and formic acids. The large persistence of Fe(III) complexes of formic acid to be photolyzed by UV light of sunlight explains the almost total mineralization attained by SPEF. The initial $\mathrm{N}$ was majority released as $\mathrm{NH}_{4}^{+}$, with a very small proportion of $\mathrm{NO}_{3}^{-}$.

Acknowledgments The authors are indebted to MINECO (Spain) by financial support under the Project CTQ2013-48897-C2-1-R, cofinanced with Feder funds. S. Garcia-Segura thanks the grant awarded by MEC (Spain).

\section{References}

1. Robinson T, McMullan G, Marchant R, Nigam P (2001) Remediation of dyes in textile effluent: a critical review on current treatment technologies with a proposed alternative. Bioresour Technol 77:247-255. doi:10.1016/S0960-8524(00)00080-8

2. Zollinger H (2003) Color chemistry: synthesis, properties, and applications of organic dyes and pigments. VHCA and Wiley-VCH, Weinheim

3. Moreira FC, Garcia-Segura S, Vilar VJP, Boaventura RAR, Brillas E (2013) Decolorization and mineralization of sunset yellow FCF azo dye by anodic oxidation, electro-Fenton, UVA photoelectroFenton and solar photoelectro-Fenton processes. Appl Catal B Environ 142-143:877-890. doi:10.1016/j.apcatb.2013.03.023

4. Khandegar V, Saroha AK (2013) Electrocoagulation for the treatment of textile industry effluent - a review. J Environ Manag 128: 949-963. doi:10.1016/j.jenvman.2013.06.043

5. Brillas E, Martínez-Huitle CA (2015) Decontamination of wastewaters containing synthetic organic dyes by electrochemical methods. An updated review. Appl Catal B Environ 166-167: 603-643. doi:10.1016/j.apcatb.2014.11.016

6. UNESCO (2012) The United Nations World Water Development Report 4, volume 1: managing water report under uncertainty and risk

7. Ulson de Souza SMAG, Forgiarini E, Ulson de Souza AS (2007) Toxicity of textile dyes and their degradation by enzyme peroxidase
(HRP). J Hazard Mater 147:1073-1078. doi:10.1016/j.jhazmat. 2007.06.003

8. Sharma KP, Sharma S, Sharma SP, Singh K, Kumar S, Grover R, Sharma PK (2007) A comparative study on characterization of textile wastewaters (untreated and treated) toxicity by chemical and biological tests. Chemosphere 69:48-54. doi:10.1016/j. chemosphere.2007.04.086

9. Forgacs E, Cserháti T, Oros G (2004) Removal of synthetic dyes from wastewaters: a review. Environ Int 30:953-971. doi:10.1016/ j.envint.2004.02.001

10. dos Santos AB, Cervantes FJ, van Lier JB (2007) Review paper on current technologies for decolourisation of textile wastewaters: perspectives for anaerobic biotechnology. Bioresour Technol 98:23692385. doi:10.1016/j.biortech.2006.11.013

11. Vilar VJP, Pinho LX, Pintor AMA, Boaventura RAR (2011) Treatment of textile wastewaters by solar-driven advanced oxidation processes. Sol Energy 85:1927-1934. doi:10.1016/j.solener. 2011.04.033

12. Sirés I, Brillas E, Oturan MA, Rodrigo MA, Panizza M (2014) Electrochemical advanced oxidation processes: today and tomorrow. A review. Environ Sci Pollut Res 21:8336-8367. doi:10.1007/ s11356-014-2783-1

13. Vasudevan S, Oturan MA (2014) Electrochemistry: as cause and cure in water pollution - an overview. Environ Chem Lett 12:97108. doi:10.1007/s10311-013-0434-2

14. Lahkimi A, Oturan MA, Oturan N, Chaouch M (2007) Removal of textile dyes from water by the electro-Fenton process. Environ Chem Lett 5:35-39. doi:10.1007/s10311-006-0058-x

15. Panizza M, Cerisola G (2009) Electro-Fenton degradation of synthetic dyes. Water Res 43:339-344. doi:10.1016/j.watres.2008.10. 028

16. Garcia-Segura S, Centellas F, Arias C, Garrido JA, Rodríguez RM, Cabot PL, Brillas E (2011) Comparative decolorization of monoazo, diazo and triazo dyes by electro-Fenton process. Electrochim Acta 58:303-311. doi:10.1016/j.electacta.2011.09.049

17. Wang A, Qu J, Liu H, Ru J (2008) Mineralization of an azo dye acid red 14 by photoelectro-Fenton process using an activated carbon fiber cathode. Appl Catal B Environ 84:393-399. doi:10.1016/j. apcatb.2008.04.016

18. Zarei M, Khataee AR, Ordikhani-Seyedlar R, Fathinia M (2010) Photoelectro-Fenton combined with photocatalytic process for degradation of an azo dye using supported $\mathrm{TiO}_{2}$ nanoparticles and carbon nanotube cathode: neural network modeling. Electrochim Acta 55:7259-7265. doi:10.1016/j.electacta.2010.07.050

19. Khataee A, Khataee A, Fathinia M, Vahid B, Joo SW (2013) Kinetic modeling of photoassisted-electrochemical process for degradation of an azo dye using boron-doped diamond anode and cathode with carbon nanotubes. J Ind Eng Chem 19:1890-1894. doi:10.1016/j.jiec.2013.02.037

20. Garcia-Segura S, El-Ghenymy A, Centellas F, Rodríguez RM, Arias C, Garrido JA, Cabot PL, Brillas E (2012) Comparative degradation of the diazo dye direct yellow 4 by electro-Fenton, photoelectro-Fenton and photo-assisted electro-Fenton. J Electroanal Chem 681:36-43. doi:10.1016/j.jelechem.2012.06.002

21. Florenza AX, Solano AMS, Centellas F, Martínez-Huitle CA, Brillas E, Garcia-Segura S (2014) Degradation of the azo dye Acid Red 1 by anodic oxidation and indirect electrochemical processes based on Fenton's reaction chemistry. Relationship between decolorization, mineralization and products. Electrochim Acta 142: 276-288. doi:10.1016/j.electacta.2014.07.117

22. Panizza M, Cerisola G (2009) Direct and mediated anodic oxidation of organic pollutants. Chem Rev 109:6541-6569. doi:10.1021/ cr9001319

23. Flox C, Arias C, Brillas E, Savall A, Groenen-Serrano K (2009) Electrochemical incineration of cresols: a comparative study 
between $\mathrm{PbO}_{2}$ and boron-doped diamond anodes. Chemosphere 74:1340-1347. doi:10.1016/j.chemosphere.2008.11.050

24. Brillas E, Garcia-Segura S, Skoumal M, Arias C (2010) Electrochemical incineration of diclofenac in neutral aqueous medium by anodic oxidation using Pt and boron-doped diamond anodes. Chemosphere 79:605-612. doi:10.1016/j.chemosphere. 2010.03.004

25. Sopaj F, Rodrigo MA, Oturan N, Podvorica FI, Pinson J, Oturan MA (2015) Influence of the anode materials on the electrochemical oxidation efficiency. Application to oxidative degradation of the pharmaceutical amoxicillin. Chem Eng J 262:286-294. doi:10. 1016/j.cej.2014.09.100

26. Flox C, Garrido JA, Rodríguez RM, Cabot PL, Centellas F, Arias C, Brillas E (2007) Mineralization of herbicide mecoprop by photoelectro-Fenton with UVA and solar light. Catal Today 129: 29-36. doi:10.1016/j.cattod.2007.06.049

27. Garcia-Segura S, Almeida LC, Bocchi N, Brillas E (2011) Solar photoelectro-Fenton degradation of the herbicide 4-chloro-2methylphenoxyacetic acid optimized by response surface methodology. J Hazard Mater 194:109-118. doi:10.1016/j.jhazmat.2011. 07.089

28. Ruiz EJ, Hernández-Ramírez A, Peralta-Hernández JM, Arias C, Brillas E (2011) Application of solar photoelectro-Fenton technology to azo dyes mineralization: effect of current density, $\mathrm{Fe}^{2+}$ and dye concentration. Chem Eng J 171:385-392. doi:10.1016/j.cej. 2011.03.004

29. Isarain-Chávez E, Rodríguez RM, Cabot PL, Centellas F, Arias C, Garrido JA, Brillas E (2011) Degradation of pharmaceutical betablockers by electrochemical advanced oxidation processes using a flow plant with a solar compound parabolic collector. Water Res 45: 4119-4130. doi:10.1016/j.watres.2011.05.026

30. El-Ghenymy A, Garcia-Segura S, Rodríguez RM, Brillas E, El Begrani MS, Abdelouahid BA (2012) Optimization of the electroFenton and solar photoelectro-Fenton treatments of sulfanilic acid solutions using a pre-pilot flow plant by response surface methodology. J Hazard Mater 221-222:288-297. doi:10.1016/j.jhazmat. 2012.04.053

31. Garcia-Segura S, Brillas E (2014) Advances in solar photoelectroFenton: decolorization and mineralization of the direct yellow 4 diazo dye using an autonomous solar pre-pilot plant. Electrochim Acta 140:384-395. doi:10.1016/j.electacta.2014.04.009

32. Thiam A, Sirés I, Brillas E (2015) Treatment of a mixture of food color additives (E122, E124 and E129) in different water matrices by UVA and solar photoelectro-Fenton. Water Res 81:178-187. doi:10.1016/j.watres.2015.05.057

33. Garcia-Segura S, Brillas E (2016) Combustion of textile monoazo, diazo and triazo dyes by solar photoelectro-Fenton: decolorization, kinetics and degradation routes. Appl Catal B Environ 181:681691. doi:10.1016/j.apcatb.2015.08.042

34. Chacon JM, Leal MT, Sanchez M, Bandala ER (2006) Solar photocatalytic degradation of azo-dyes by photo-Fenton process. Dyes Pigments 69:144-150. doi:10.1016/j.dyepig.2005.01.020

35. Myers RH, Montgomery DC (2002) Response surface methodology. Wiley, New York

36. Bezerra MA, Santelli RE, Oliveira EP, Villar LS, Escaleira LA (2008) Response surface methodology (RSM) as a tool for optimization in analytical chemistry. Talanta 76:965-977. doi:10.1016/j. talanta.2008.05.019
37. Vinodgopal K, Peller J (2003) Hydroxyl radical-mediated advanced oxidation processes for textile dyes: a comparison of the radiolytic and sonolytic degradation of the monoazo dye acid orange 7. Res Chem Intermed 29:307-316. doi:10.1163/156856703764929967

38. Yuan R, Ramjaun SN, Wang Z, Liu J (2011) Effects of chloride ion on degradation of acid orange 7 by sulfate radical-based advanced oxidation process: implications for formation of chlorinated aromatic compounds. J Hazard Mater 196:173-179. doi:10.1016/j. jhazmat.2011.09.007

39. More P, Swami D, Pandey H, Pare B (2012) Photocatalytic mineralization of orange II dye utilizing $\mathrm{ZnO}$ in presence of visible light. Int J Chem Sci 10:1549-1564, ISSN 0972-768X

40. Horakova M, Klementova S, Kriz P, Pavel B, Balakrishna SK, Spatenka P, Golovko O, Hajkova P, Exnar P (2014) The synergistic effect of advanced oxidation processes to eliminate resistant chemical compounds. Surf Coat Technol 241:154-158. doi:10.1016/j. surfcoat.2013.10.068

41. Shi P, Zheng H, Yao W, Wu Q, Tan S, Pang H (2014) Study on the loadings of $\mathrm{Co}_{3} \mathrm{O}_{4}$ supported on $\mathrm{rGO}$ as the catalyst for degradation of orange II in water by AOPs based on sulfate radicals. Adv Mater Res 955-959:62-65. doi:10.4028/www.scientific.net/AMR.955959.62

42. Peralta-Hernandez JM, Meas-Vong Y, Rodriguez FJ, Chapman TW, Maldonado MI, Godinez LA (2007) Comparison of hydrogen peroxide-based processes for treating dye-containing wastewater: decolorization and destruction of orange II azo dye in dilute solution. Dyes Pigments 76:656-662. doi:10.1016/j.dyepig.2007.01. 001

43. Daneshvar N, Aber S, Vatanpour V, Rasoulifard MH (2008) Electro-Fenton treatment of dye solution containing orange II: influence of operational parameters. J Electroanal Chem 615:165174. doi:10.1016/j.jelechem.2007.12.005

44. Hammami S, Bellakhal N, Oturan N, Oturan MA, Dachraoui M (2008) Degradation of acid orange 7 by electrochemically generated ${ }^{\circ} \mathrm{OH}$ radicals in acidic aqueous medium using a boron-doped diamond or platinum anode: a mechanistic study. Chemosphere 73:678-684. doi:10.1016/j.chemosphere.2008.07.010

45. Özcan A, Oturan MA, Oturan N, Sahin Y (2009) Removal of acid orange 7 from water by electrochemically generated Fenton's reagent. J Hazard Mater 163:1213-1220. doi:10.1016/j.jhazmat. 2008.07.088

46. Elias B, Guihard L, Nicolas S, Fourcade F, Amrane A (2011) Effect of electro-Fenton application on azo dyes biodegradability. Environ Prog Sustainable Energy 30:160-167. doi:10.1002/ep.10457

47. Lin H, Zhang H, Wang X, Wang L, Wu J (2014) Electro-Fenton removal of orange II in a divided cell: reaction mechanism, degradation pathway and toxicity evolution. Sep Purif Technol 122:533540. doi:10.1016/j.seppur.2013.12.010

48. Bañuelos JA, Garcia-Rodriguez O, Rodriguez-Valadez FJ, Godinez LA (2015) Electrochemically prepared iron-modified activated carbon electrodes for their application in electro-Fenton and photoelectro-Fenton. J Electrochem Soc 162:E154-E159. doi:10. 1149/2.0581509jes

49. Box GEP, Draper NR (1987) Empirical model-building and response surfaces. Wiley, New York

50. Bruns RE, Scarminio IS, Neto BB (2006) Statistical designchemometrics. Elsevier, Amsterdam 